\title{
PERCEPTION OF NON-MALAY MALAYSIANS TOWARDS THE JAWI SCRIPT AS A NATIONAL HERITAGE
}

\author{
Ahmad Fahmi RAMLI* \\ Kulliyyah of Islamic Revealed Knowledge \& Human Sciences \\ International Islamic University Malaysia, Selangor, Malaysia \\ fahmismaszal@gmail.com
}

Manuscript received 7 October 2020

Manuscript accepted 31 May 2021

*Corresponding author

https://doi.org/10.33736/ils.2643.2021

\begin{abstract}
The Jawi script is a Malay traditional writing system adapted from the Arabic alphabet which was once used widely during the reign of the British Empire before Romanisation of the Malay writing system took place. It is regarded as a national heritage of Malaysia due to the fact that Bahasa Melayu is the national language of the country. There have been many initiatives taken by the government in preserving the Jawi script including the insertion of Jawi lessons in the Bahasa Melayu subject at the primary school level. However, the new education policy has roused an argument among Malaysians, particularly non-Malays who have been in disagreement towards the new syllabus implemented. The study examined the perceptions and attitudes of non-Malays in Malaysia towards the Jawi script. This descriptive study involved 30 respondents who were approached and invited to participate in the survey. The result portrayed that the participants showed neutral perceptions towards the Jawi script on the basis that it has its own artistic values that should be preserved.
\end{abstract}

Keywords: Jawi script; Bahasa Melayu; non-Malays; perception; national heritage 


\section{Introduction}

The Jawi script is a traditional writing system of Bahasa Melayu which once had been used widely before the colonisation of the British Empire in Malaysia. It was changed to the Roman alphabet commonly used in English. Jawi was used "for written communication as in dealing with government affairs like the practice of the Sultan of Acheh who used to write letters in Jawi to Sir James Lancaster (1601M) for business purposes" (Amin et al., 2018, p. 3). It is believed that the change was made to ease communication between the people and officials. Today, the Jawi script is still being used as can be seen on billboards, bank notes, logos, and the coat of arms of Malaysia. In 2019, the Ministry of Education Malaysia decided to implement a new policy that involved the inclusion of the Jawi script in the Malay language subject for primary school students (Babulal, 2019). This caused a stir among members of the public, especially Malays and Non-Malays who regarded the new policy as an example of a racist practice. However, a large segment of the Malaysian public viewed the policy positively because the Jawi script is a national heritage that should be preserved. This is attested by The Federal Constitution of Malaysia under the National Language Acts 1963/67 which states that "the script of the national language shall be the Rumi script: provided that this shall not prohibit the use of the Malay script, more commonly known as the Jawi Script, of the national language" (Attorney General's Chambers of Malaysia, 2006).

Nevertheless, everyone has the right to voice out his or her opinions and thoughts regarding issues that arise in Malaysia. The non-Malays may have their personal views about the Jawi script and this needs to be investigated to redress the perception that all non-Malays are against it. Therefore, this study investigated the perception of the Jawi script among non-Malay Malaysians. Specifically, the study aimed to examine the perceptions of non-Malay Malaysians towards the Jawi script as a national heritage and their language attitudes towards the Jawi script.

\section{Literature Review}

Language attitude is the evaluation of language by an individual, the way people behave towards a language. Lanos (2014) stated that language attitude reflects the tendency to evaluate a language favourably or unfavourably. Generally, attitude is a conceptualisation of an issue and from the context of language, it portrays the action and reaction of an individual towards the language used or the process of acquiring the language - "People develop attitudes towards languages which indicate their views about those who speak the languages, and the contexts and functions with which they are associated." (Holmes, 2013, p. 410).

There are three main components of language attitude explained by Ladeegard (2000) which are knowledge, emotion and behaviour. Knowledge in language attitude refers to the general idea about the language either it is the first or second language in the region, or the status of the language itself in that region. By asking some questions about a language and analysing the idea from responses given by the respondents, it can help researchers to evaluate the respondents' knowledge level of the language. Secondly, an emotion can be explained through 
people's feelings towards a language, whether a language is accepted with a warm heart or not. Lastly, behaviour can be evaluated through the actions taken towards understanding a language, that is, how often people use and practise the language and how it is treated in the society.

Baker (1992, as cited in Lanos, 2014) underlined several concepts of language attitude that can be taken into account by researchers who are interested in this area of study: Attitude towards language, attitude towards language variety or dialect, attitude towards speakers of a specific language or variety, attitude towards language learning, attitude towards the learning situation, attitude towards language related behaviours, such as language use, language maintenance, and planning behaviours.

Apart from that, language attitude is not necessarily a study of attitude towards a language but it can be any element that is related to the language such as a writing system, an acquisition or a practical aspect. A study conducted by Amin et al. (2018) regarding the perception of UiTM students towards teaching and learning of Jawi at various levels of education showed a positive view among all the respondents. They preferred the Jawi script to be used extensively and recommended that the government should promote the use of Jawi widely. The positive perception of the Jawi script is due to the fact that all respondents were Malays who felt positively about their native language. Another study on the Jawi script was conducted by Amin et al. (2017) on the perception of Malay students towards the capability of the Jawi script as an indicator of Malay identity and Malay cultural heritage. The result showed that the respondents had positive thoughts and enthusiasm in retaining the Jawi script since it is part of the Malay identity and cultural heritage. Studies on the Jawi script have been done in other countries. Yusof and Sulaiman (2015) who conducted a study on the perception of university students in Brunei towards the Jawi script. The study revealed that the students regularly used the Jawi script in their daily lives, not only for academic purposes, but, also for personal uses such as name tag, signature and car plate.

The previous studies that focused on the Malays' perception towards Jawi script have been done and the results depicted the positive attitude of the respondents towards the Jawi script. This due to the original ethnicity of the respondents which were all Malays and that could influence their attitude towards their own cultural writing system, Jawi script. Therefore, by conducting this research, it could fill the gap which the respondents selected for this study were all non-Malays. So, this would lead to different perceptions towards Jawi script compared to previous studies that have been conducted.

\section{Research Methodology}

The study was a descriptive study involving 30 non-Malay respondents who answered the questionnaires. This considered as a descriptive study because it explains the phenomenon or issue of the study conducted. The main goal of descriptive research it to explain and describe the phenomenon and its characteristics (Nassaji, 2015). The respondents were selected randomly through the distribution of online questionnaire by using Google Form. The small number of 
respondents may not represent the whole population of the non-Malays in Malaysia, thus this study cannot be regarded as quantitative research but rather it is the descriptive one. The respondents were not asked to expose their personal detail like name, contact number, etc, so the anonymity was remained.

The biggest number of respondents were Chinese (66.7\%), followed by Indians and then other races (e.g., mixed race and the Kadazan Dusun). The majority of respondents were young people between 18 to 40 years old (93.3\%). Most of them had an intermediate level of Bahasa Melayu proficiency. Most respondents could write and speak Bahasa Melayu well. Regarding their first and second languages, the majority of participants speak their native language as their first language and it is surprising to note that English has become their second language rather than Bahasa Melayu, the national language of Malaysia. This would be a factor reflecting their perception towards the Jawi script as the national heritage of Malaysia.

The instrument for data collection was a questionnaire that consisted of two sections with 10 Likert-scale based questions each, and one open-ended question for the respondents to express their opinions regarding this subject under study. The open-ended question was "In your own personal opinion, do you think it is a must as a Malaysian to acknowledge the Jawi script? Why?" The questions were adapted from Amin et al. (2017) who studied the Jawi script issue. The questionnaire was constructed using Google Form and distributed to the respondents through online platforms.

Descriptive analysis of the questionnaire data was conducted. For the openended question, the data were coded into themes associated with the responses given by all the respondents.

\section{Results}

Table 1 shows perceptions of the Jawi script as a representation of national identity based on their level of agreement with the 10 statements ( $S D=S$ trongly disagree, $D=$

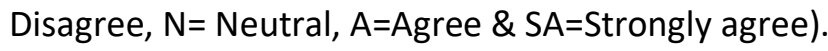

\section{Table 1}

Perceptions towards the Jawi Script as a Representation of National Identity

\begin{tabular}{clllllll}
\hline No. & \multicolumn{1}{c}{ Questions } & SD & D & N & A & SA \\
\hline 1 & $\begin{array}{l}\text { The ability to use the Jawi script well can } \\
\text { strengthen my identity as a Malaysian. }\end{array}$ & 14 & 5 & 8 & 1 & 2 \\
2 & $\begin{array}{l}\text { The ability to use the Jawi script well can be } \\
\text { the indicator for a true identity of Malaysian. }\end{array}$ & 15 & 4 & 8 & 2 & 1 \\
3 & $\begin{array}{l}\text { Learning the Jawi script can influence you to } \\
\text { become a Muslim. }\end{array}$ & 15 & 9 & 5 & 1 & - \\
4 & $\begin{array}{l}\text { As a non-Malay Malaysian, I will feel proud if I } \\
\text { can read and write the Jawi script well. }\end{array}$ & 3 & 2 & 6 & 12 & 7 \\
5 & $\begin{array}{l}\text { As a non-Malay Malaysian, I feel the } \\
\text { importance of learning the Jawi script. }\end{array}$ \\
6 & 10 & 6 & 11 & 3 & - \\
If Malaysians feel reluctant to learn the Jawi & 16 & 6 & 7 & 1 & -
\end{tabular}


script, it means they are not proud of the national language.

7 As a non-Malay Malaysian, I have a right to question the obligation of learning the Jawi script.

8 Learning the Jawi script is a process of Islamising the national education system.

9 Mastering the Jawi script will transform you to become a Malay.

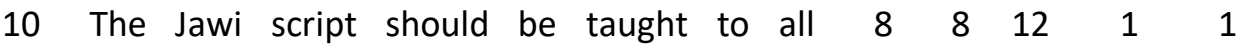
Malaysians.

Firstly, on "the ability to use the Jawi script can strengthen a Malaysian's identity", the majority of respondents strongly disagreed and only a few of them agreed or strongly agreed with that statement. Next, on "the Jawi script mastery as an indicator for a Malaysian's true identity", most of the respondents strongly disagreed with the statement as well as only a few agreed and strongly agreed. The third item on "the Jawi script may influence you to become a Muslim" portrayed the strongest disagreement by the respondents and only one respondent agreed with the statement. The fourth item which is on "the pride of mastering the Jawi script" shows a high agreement among the respondents and only a few of them strongly disagreed or disagreed. There was a balanced number of respondents who strongly disagreed and were neutral on "the importance of learning Jawi" while a few of them firmly agreed with the statement. The majority of respondents strongly disagreed with the statement, "the reluctance of learning Jawi reflects their level of acceptance towards Bahasa Melayu as the national language", while only one of them agreed. "The right of questioning the obligatory Jawi script learning" shows a balanced number of respondents strongly agreed or agreed with the statement, while only a small number of them disagreed. Many respondents indicated a neutral stance on "the Islamisation of the national education system". The statement "mastering the Jawi script will transform you to become a Malay" received the strongest disagreement. Lastly, the majority of the respondents showed a neutral attitude towardsthe suggestion of implementing the learning of the Jawi script in primary schools and only two of them agreed. However, if both levels of "strongly disagree" and "disagree" were summed, the results showed that the number of respondents who disagreed was higher than the number who chose to be "neutral" on the Jawi script as the representation of national identity. 
Table 2

Perceptions towards the Jawi Script as a National Heritage

\begin{tabular}{|c|c|c|c|c|c|c|}
\hline No. & Questions & SD & $\mathrm{D}$ & $\mathrm{N}$ & A & SA \\
\hline 1 & $\begin{array}{l}\text { The Jawi script should be preserved as a national } \\
\text { heritage of Malaysia. }\end{array}$ & 2 & 5 & 14 & 8 & 1 \\
\hline 2 & $\begin{array}{l}\text { The use of Jawi script should be used widely } \\
\text { in/throughout Malaysia. }\end{array}$ & 7 & 8 & 11 & 3 & 1 \\
\hline 3 & $\begin{array}{l}\text { Mastering the Jawi script can help Malaysians to } \\
\text { appreciate the national language. }\end{array}$ & 9 & 10 & 8 & 2 & 1 \\
\hline 4 & $\begin{array}{l}\text { The Jawi script has its own unique and artistic } \\
\text { values that should be known among Malaysians. }\end{array}$ & 3 & 2 & 16 & 7 & 2 \\
\hline 5 & $\begin{array}{l}\text { The Jawi script does not portray the beauty of } \\
\text { Bahasa Melayu but instead the influence of } \\
\text { Arabic language. }\end{array}$ & - & 5 & 15 & 4 & 6 \\
\hline 6 & $\begin{array}{l}\text { The use of the Jawi script should be inherited } \\
\text { from generation to generation. }\end{array}$ & 1 & 7 & 14 & 4 & 4 \\
\hline 7 & $\begin{array}{l}\text { Theinclusion of the Jawi script lessons in the } \\
\text { bahasa Melayu subject at the primary school } \\
\text { level should not be objected because it gives an } \\
\text { early exposure on the beauty of the national } \\
\text { language. }\end{array}$ & 3 & 9 & 13 & 3 & 2 \\
\hline 8 & $\begin{array}{l}\text { The Jawi script is the original written system of } \\
\text { Bahasa Melayu (the national language), thus it } \\
\text { should be mastered by all Malaysians. }\end{array}$ & 11 & 6 & 10 & 1 & 2 \\
\hline 9 & $\begin{array}{l}\text { The use of the Jawi script for any international } \\
\text { programmes that represent Malaysia's culture } \\
\text { should be prioritised. }\end{array}$ & 7 & 11 & 9 & 3 & - \\
\hline 10 & $\begin{array}{l}\text { The Jawi script is not necessary to be } \\
\text { acknowledged by Malaysians. }\end{array}$ & 1 & 7 & 16 & 4 & 2 \\
\hline
\end{tabular}

Table 2 shows the results on perceptions towards the Jawi script as a national heritage. On the first statement regarding "the perseverance of the Jawi script as a national heritage", most respondents showed a neutral stance and only a few of them agreed or disagreed with the statement. Secondly, most of the respondents chose to be neutral regarding "the augmentation of the Jawi script usage in Malaysia", however, if the numbers of strongly disagree and disagree were summed up, they are higher. Most respondents disagreed with the third statement on "mastering the Jawi script as an appreciation for the national language". Next, many respondents were neutral towards the statement on "acknowledgment of the Jawi script among Malaysians". Only a few respondents disagreed with the statement on "the influence of Arabic in the Jawi script" and the majority chose to be neutral. Most respondents also preferred to be neutral in their views on "the inheritance of the Jawi script to the new generation" while only one of them strongly disagreed. A large number of respondents were neutral on "the objection of the Jawi script subtopic to be included in the Bahasa Melayu subject at the primary school level". The number of respondents who strongly disagreed with the 
statement on "mastering the Jawi script due to its origin in the Bahasa Melayu writing system" was the highest and only a a few of them agreed. For the Item 9, many respondents strongly disagreed with "the priority of using the Jawi script in any international programmes to represent Malaysia's culture" and only three respondents agreed with the statement. Lastly, a majority of the respondents were neutral towards the statement "the Jawi script is not important for Malaysians to acknowledge".

Table 3

Attitudes towards the Jawi Script among Malaysians

\begin{tabular}{cl}
\hline Attitude & Responses \\
\hline Positive & Additional knowledge \\
& Aesthetic value of Bahasa Melayu \\
Neutral & Voluntary basis \\
& Invaluable \\
Negative & Religious cultural element \\
& Bad impact \\
\hline
\end{tabular}

Table 3 presents the results analysed from the open-ended question - In your own personal opinion, do you think it is a must as a Malaysian to acknowledge the Jawi script? Why? Referring to the positive perception, the respondents acknowledged that the Jawi script among Malaysians is a must because it is regarded as an additional knowledge especially among Non-Malays to enhance their communication skills. The positive responses given by the respondents also portrayed appreciation of the aesthetic values of Bahasa Melayu as the Jawi script is the original writing system of Bahasa Melayu and historically, it was once used widely in the country's formal affairs.

As for the neutral perception, the responses given were generally about voluntary acknowledgement of the Jawi script. In other words, non-Malay Malaysians can opt to learn or not to learn the Jawi script and that it should not be compulsory as stipulated in the restructuring of the Bahasa Melayu curriculum at the primary school level.

There were also negative responses to the question on whether it is a must as a Malaysian to acknowledge the Jawi script. The respondents claimed that that the Jawi script is not valuable to be acknowledged because it does not give any beneficial values for them to know the writing system. In fact, they argued that the Jawi script has no cultural element of Bahasa Melayu at all. Instead it is just an influence of Arabic and Islamic cultures. They added that learning the Jawi script would further burden non-Malay Malaysian students because bahasa Melayu is a compulsory subject in Sijil Pelajaran Malaysia (SPM) examination. 


\section{Discussion}

From the results, the respondents were very moderate in their perceptions towards the Jawi script. The respondents tended to disagree when they were asked about the representation of the Jawi script as a national identity. They believed that empowering the Jawi script did not make any sense in terms of strengthening one's national identity. They opined that bahasa Melayu empowerment is enough to ensure a Malaysian citizen to have a strong identity because bahasa Melayu has served and continues to serve as a national language of Malaysia. Furthermore, the narrative of saying that non-Malays are afraid of learning the Jawi Script as it can transform them into a Malay is unfounded since the majority of the respondents strongly disagreed with such this statement. Nevertheless, they had the perception that the Jawi Script is not originally associated with the identity of bahasa Melayu, but rather influenced by the Arabic script. This had aroused some fears among the non-Malays who claimed that the inclusion of the Jawi script in the primary school bahasa Melayu lessons is a hidden agenda by the government to Islamise the national education system. Some criticisms have been expressed by the non-Malay community like the Dong Zong Association who campaigned for a petition to abandon the Jawi script lessons in the vernacular schools ("Dong Zong Insists Khat Lesson is Islamisation, Starts Petition", 2019). They argued that the implementation of the Jawi script in the bahasa Melayu lessons would affect the faith of the nonMalay Malaysian students since the Jawi script has similar characteristics with the Arabic script. They also assumed that the government was Islamising the national education system. Rosli (2016) had rejected the concept of defining the process of Arabisation as similar to Islamisation because there is no bridge between both concepts. The same action was taken by the Malaysian Indian Education Transformation Association who held a protest after the Ministry of Education, Malaysia announced the new syllabus structure for Bahasa Melayu at the primary school level that included Jawi lessons (Yap, 2019). They protested for the right to not make it compulsory for the vernacular schools to adopt the new bahasa Melayu syllabus. The reaction towards the Jawi script spread to East Malaysia where the Sabah state government had decided to make Jawi an optional instead of a compulsory topic in the new bahasa Melayu syllabus (Borneo Post, 2019). Although the Sabah government intended to make Jawi lessons as an option, they did not disregard the historical value of the Jawi script as the old writing system of Bahasa Melayu. Due to the fact that the Roman script has been widely used, they suggested that the Jawi script should be upgraded into a specific subject, just like Advanced Mathematics or English Literature, which would allow sufficient Jawi content to be delivered for those who are interested to learn the Jawi script. The mixed reactions from all communities in Malaysia show that non-Malay Malaysians hold personal views on the new policy.

In addition, the results showed that the respondents expressed a neutral stance on the Jawi script as a national heritage. They believed the Jawi script has a high artistic value that should be exposed to all Malaysians. However, the respondents felt that obliging non-Malay Malaysians to acknowledge the traditional writing system of Bahasa Melayu is unnecessary. Although the respondents showed 
much respect for the Jawi script, they argued that it is symbolizes a Malay cultural identity and it had nothing to do with the country's national heritage. They understood the concept of bahasa Melayu as the national language, but, at the same time, they felt the irrelevance of mastering the Jawi script. Some of the respondents mentioned that there is no demand for them to master the Jawi script since there is no working requirement for Jawi knowledge or skill qualification. This is one of the reasons why non-Malay Malaysians have questioned the government on its decision to make the Jawi script a compulsory subtopic in the Bahasa Melayu subject to be taught in national. Nonetheless, this reason is contradictory to what has been expected by most Malay Malaysians who claim that their non-Malay counterparts reject the idea of having Jawi lessons in primary schools. Based on the results, nonMalay Malaysians have a positive perception towards the Jawi script lessons at schools, but with one condition, that is to make the Jawi script as an optional choice among students. This is supported by Amin et al. $(2018$, p. 8$)$ who stated that "the respondents apparently possess positive views towards the exposure and practice of Jawi at various levels of education".

As the Jawi script has the influence of the Arabic writing system, the respondents held a different attitude towards the writing system. The majority of them chose to be neutral. They could accept the Jawi script as an artistic value of Bahasa Melayu, but somehow misunderstood the Jawi script as reflecting the Islamic religion due to the characteristics of the Jawi script being similar to the Arabic alphabet. Most non-Malay Malaysians claimed that that Arabic is not simply a language of human being, but more towards Islamic language (Nasir, Zainuddin, \& Shahrir, 2017). Moreover, there were some negative feedback whereby the respondents questioned the necessity of acknowledging the Jawi script by claiming that ithas no prestigious value compared to English. Amin and Rahman (2018, p. 1000 ) stated that "the respondents (non-Malays) in majority still prefer English as a more universal one to be used for inter-racial communication in Malaysia".

\section{Conclusion}

This study aims to discover the perception of non-Malay Malaysians towards Jawi script as the national heritage of Malaysia. The perception of the non-Malay Malaysians towards the Jawi script is not as negative as it has been previously thought. This study revealed that the non-Malays were neutral towards the issue and accept the Jawi script as the national identity as well as a heritage despite their personal opinions about the subject matter. From the findings, the level of knowledge of the Jawi script has shaped the attitude of the non-Malay Malaysians towards Jawi script. Thus there are different stances among them in answering the survey. This study is very important because it provides some insights into the the perception of non-Malays towards the Jawi script and how such insights can help address the argument that it has raised among many Malaysians. The implication of this study is it opens the eyes of Malaysians to be more rational in understanding a racial issue because different races may have different views about cultural issues. Therefore, from the finding has proven that the non-Malays are not extremely against the Jawi script like what have been viral on the media. In addition, the 
finding has shown neutral stance among the respondents when it comes to the thought that Jawi lesson is a part of islamising the national education system because the non-Malays may be misunderstood with the character of Jawi script that seemly looks like Arabic, the language of Islam. This surely will trigger them to not let their children get influenced of becoming a muslim or Malay. Thus, it is crucial to take into account of their feelings, voices and thoughts since Malaysia is a multiracial country and this can be very sensitive issue to the non-Malay Malaysians. In addition, the Malays also need to play their role to explain Jawi thoroughly to non-Malays so they will get a clear notion of how Jawi is associated with Bahasa Melayu. It is fully understood that non-Malays feel threatened if the implementation of Jawi may affect their beliefs and cultural identities. Therefore, instead of making an issue of the Jawi, it would be more harmonious if all races can promote their own traditional calligraphy writings too so their cultural traditions can be acknowledged also. Hence, there is nothing wrong in promoting a cultural writing system; Jawi has been specified as it is integral to Bahasa Melayu, the national language of Malaysia. It is important to note that the study was done in a short period of time with a small sample size that does not represent the whole population of the non-Malays in Malaysia. Thus, it will be good for the future researcher to expand the amount of respondents that represent the whole population of non-Malay Malaysians. However, this study could be a catalyst for future researchers to conduct more studies on the Jawi script with an interdisciplinary research approach. For example, interrelated the issue of Jawi script with the historical factors that probably triggered some non-Malays to shape their idea of accepting the Jawi script. So, this should be involved with the study of language and history.

\section{References}

Amin, N. M., \& Rahman, N. A. (2018). The attitude of non-Malays towards Malay and English Language and their perception on language choice (Malay or English) for multi-racial communication in Malaysia: A study on non-Malay tertiary students (UNITEN). International Journal of Engineering \& Technology, 7(4.38), 996-1000. http://dx.doi.org/10.14419/ijet.v7i4.38.27625

Amin, N. M., Rahman, N. A., \& Razali, W. N. (2017). The perception of UNITEN students towards the capability to use Jawi as an indicator of Malay identity and Jawi script as Malays' cultural heritage. International Academic Research Journal of Social Science, 3(1), 159-165.

Amin, N. M., Rahman, N. A., \& Razali, W. N. (2018). The perception of UiTM students towards teaching and learning of Jawi at various levels of education in Malaysia: What should we do to expand its mastery?. Paper presented at UiTM Penang Academy of Language Studies (UPALS) Language Colloquium 2018.

https://ir.uitm.edu.my/id/eprint/26951/1/AJ_NORAZIAH\%20MOHD\%20AMI N\%20IJMAL\%20APB\%20SA\%2019\%20id_26951.pdf

Attorney General Chamber's of Malaysia. (2006). The Federal Constitution of Malaysia under the National Language Acts 1963/67. Malayan Law Journal Sdn. Bhd. 
Babulal, V. (2019, August 8). Cabinet approves khat lessons in Year 4 BM syllabus next year. New Straits Times. https://www.nst.com.my/news/governmentpublic-policy/2019/08/511250/cabinet-approves-khat-lessons-year-4-bmsyllabus-next

Dong Zong insists Khat lesson is Islamisation, starts petition. (2019, August 10). Malaysiakini. https://www.malaysiakini.com/news/487483

Holmes, J. (2013). An Introduction to Sociolinguistics (4th ed.). New York. Routledge. http://lib.perdana.org.my/PLF/GOVERNMENT\%20PUBLICATION/Publi cation\%20Laws\%20of\%20Malaysia\%20(L.O.M)/National\%20Language \%20Act\%201963-67\%20\%5BAct\%2032\%5D.pdf

KL urged to accept Sabah's decision on Jawi lesson. (2019, December 30). Borneo Post Online. https://www.theborneopost.com/2019/12/30/kl-urged-toaccept-sabahs-decision-on-jawi-lesson/

Ladegaard, H. J. (2000). Language attitudes and sociolinguistics behaviour: Exploring attitude-behaviour relations in language. Journal of Sociolinguistics, 4(2), 214-233. https://doi.org/10.1111/1467-9481.00112

Lanos, M. A. (2014). Language attitudes in a multilingual and multicultural context: The case of autochthonous and immigrant students in Catalonia. [Unpublished doctoral dissertation]. Universitat de Lleida.

Nassaji, H. (2015). Qualitative and descriptive research: Data type versus data analysis. Language Teaching Research, 19(2), 129-132.

Nasir, M. S., Zainuddin, N., \& Sahrir, M. S. (2017). Non-Muslim students' perception towards learning Arabic language. ISLĀMIYYĀT, 39(1), 29-37. http://dx.doi.org/10.17576/islamiyyat-2017-3901-04

Rosli, M. S. (2016). Islamisasi Bahasa Melayu dan pengaruh tradisi keilmuan Islam dalam kitab pengetahuan bahasa oleh Raja Ali Haji (1808-1873). [Unpublished doctoral dissertation]. Universiti Teknologi Malaysia.

Yap, F. (2019, August 22). After ministry meeting, Indian groups to protest Jawi lessons. Malaysiakini. https://www.malaysiakini.com/news/488951

Yusof, S. B., \& Sulaiman, E. (2015). Sikap generasi muda terhadap tulisan Jawi: Kajian kes pelajar Universiti Brunei Darussalam. Southeast Asia: A Multidsiciplinary Journal, 15, 8-16. 